\title{
ASSESSMENT OF THE TYPE OF FACIAL GROWTH
}

\author{
Vesna Obradović1,2, Tatjana Kanjevac 1,2, Vesna Jovanović3, Vera Simić ${ }^{4}$ \\ ${ }^{1}$ Medicinski fakultet Univerziteta u Kragujevcu, Kragujevac \\ 2 Zavod za stomatologiju, Kragujevac \\ 3 Visoka zdravstvena škola strukovnih studija, Beograd \\ ${ }^{4}$ Medicinska škola, Beograd
}

\section{PROCENA TIPA RASTA LICA}

\author{
Vesna Obradovic1,2, Tatjana Kanjevac 1,2, Vesna Jovanovic ${ }^{3}$, Vera Simic ${ }^{4}$ \\ ${ }^{1}$ Medical Faculty University of Kragujevac, Kragujevac, Serbia \\ ${ }^{2}$ Department of Dentistry, Kragujevac, Serbia \\ ${ }^{3}$ College of Health Studies, Belgrade \\ ${ }^{4}$ Nursing School, Belgrade
}

\section{SAŽETAK}

Odnos viscerokranijuma, koga čine nazomaksilarni kompleks i mandibula, prema neurokranijumu je kod novorodjenčadi 1:8, a kod odrasle osobe po završetku rasta 1:3. Za ortodonte je važno da utvrde kako raste lice ili svaka vilica zasebno i predvide dalji rast u smislu pravilnog izbora terapije $i$ ispravljanja anomalije. Za to je potrebno uraditi profilni snimak glave tj. telerendgenografski snimak glave pacijenta. Cilj ovog rada je predstavljanje najčešće korišćenih metoda analize telerendgen snimaka čime se odredjuje tip rasta lica. Danas je poznato da rast u malom obimu traje $i$ u odraslom dobu.

Ključne reči: stomatologija; lice; vilica; rast i razvoj; radiografija, dentalna.

\section{INTRODUCTION}

Development of the whole organism and therefore the whole face goes in different directions and is of different intensity in the postnatal period. The knowledge of growth and development processes is useful for prediction of future changes during the course of a person's growth. It is thought that orthodontic therapy should not be started without the previous assessment of possible future events, because direction, location and time of growth may affect therapy, as well as retention of achieved results. The direction of face growth depends on certain face structures and their mutual relations. Depending on growth dominance in certain parts of viscerocranium, the face bones, in comparison to the skull base, can be rotated in anterior or posterior direction, which produces horizontal or vertical face types. If the growth process develops with the same intensity, we will have face growth without rotation in the region of anterior and posterior face height. If the growth is dominant in the area of posterior face height, the growth goes in forward direction, and if the growth is predominant in the area of anterior face height, the growth goes by rotating backwards (1-4).

\section{MEASUREMENTS OF FACIAL GROWTH}

The aim of this study is to present the most frequently used methods for analysis of cephalometric radiographs in

\section{ABSTRACT}

The viscerocranium to neurocranium ratio is $1: 8$ in infants, while in adults, when growth has been completed, it reduces to 1:3. For orthodontists, it is important to determine the way the face or each jaw grows and thus predict further growth so that the right therapy can be chosen or an anomaly corrected. Therefore, it is necessary to make a head profile radiograph i.e. cephalometric radiograph of the patient's head. The aim of this study is to present the most frequently used methods for analysis of the cephalograms in order to determine the type of facial growth. Today, it is known that growth persists throughout adulthood, although at a slow rate.

Key words: dentistry; face; jaw; growth and development; radiography, dental.

order to determine the type of facial growth. The cephalograms should be obtained by standard techniques, which means that the patient's head should be fixed by a cephalostat, so that the Frankfurt horizontal plane is parallel to the floor, and the median sagittal plane is parallel to the cassette and film $(2,3)$.

All cephalometric radiographs are analyzed by classic analytical methods which imply drawing soft tissue and skeletal structure on an acetate sheet and measurement of certain linear and angular parameters. All measurements on the image are performed by using a reference plane i.e., according to Enlow, the plane of the anterior cranial base, because it is the least changeable value. The plane is determined by the points NS.

In relation to the reference plane of the anterior cranial base we can determine the skeletal ratio between the maxilla and mandible in the sagittal plane based on the angles SNA and SNB, and in this way determine if the face is prognate, ortognate, or retrognate. We can also determine the skeletal ratio in the vertical line and establish whether the jaws grow rotated, i.e., whether there is anteinclination, normoinclination or retroinclination. $(3,5-8)$

In addition to the measurements for each jaw, there are methods for assessment of the type of facial growth as a whole (9-11). 
1. The metric method

- $\quad$ Bjork's polygon (figure 1)

- $\quad$ the percent ratio of the posterior to anterior face height (figure 2)

- $\quad$ the gonial angle ( figure 3)

- $\quad$ the angle of the Y-axis (figure 4)

2. The longitudinal method of superimposing successive cephalograms (figure 5)

3. The structural method of morphological features for certain type of facial growth (figure 6)

\section{The metric method}

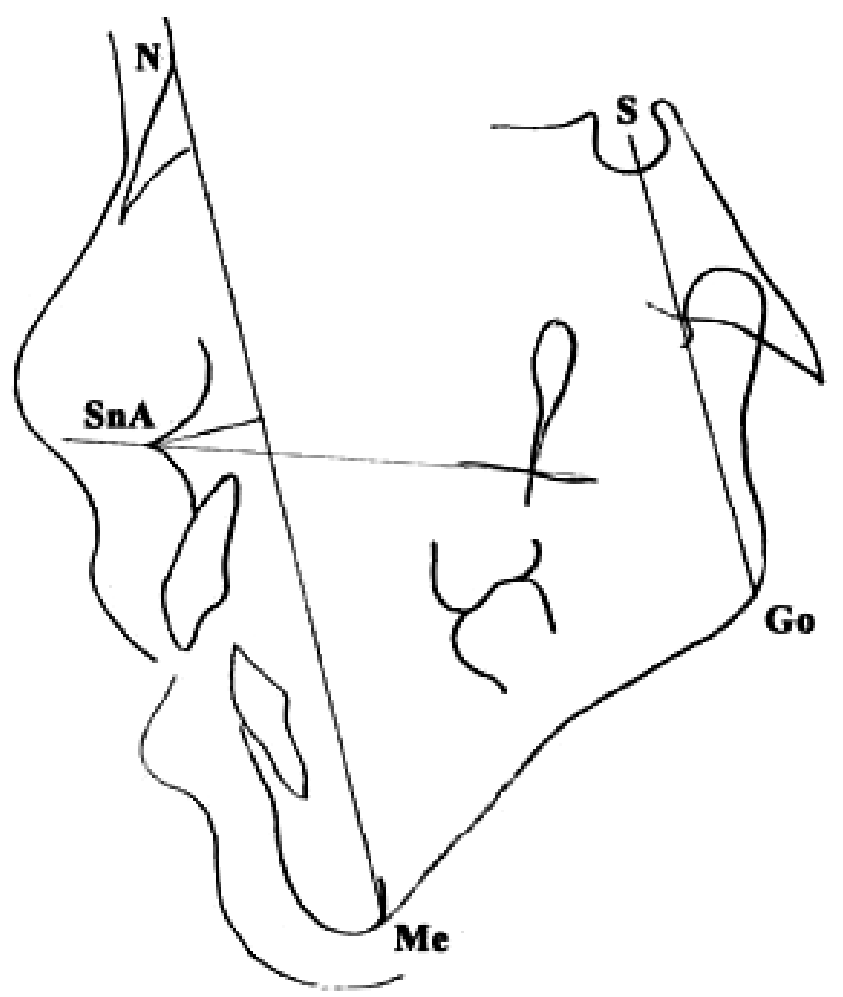

Figure 1. Angles of Bjork's polygon.

The sum of angles of Bjork's polygon tells us about the facial growth type. If the sum value is $396^{\circ}$, the facial growth is without rotation, i.e., it is a balanced horizontal and vertical facial growth. If the sum of angles is less than $396^{\circ}$ the face grows with the forward rotation, and finally, if the sum of Bjork's polygon angles is greater than this value, the face grows with the backward rotation. The maxilla and mandible can occupy different positions in the sagittal and vertical direction in relation to the anterior cranial base, and then we speak about anterior or posterior rotation of the jaws and the entire face. Here, the rotation of the mandible is two times greater than the rotation of the maxilla, which means that it gives the characteristic facial expression $(3,13,14)$. During the rotation of jaws, the following changes occur:
- $\quad$ inner changes (in the body of the bone)

- $\quad$ changes of the condyle (matrix rotation)

- $\quad$ in the centre of the body of the bone (intramatrix rotation)

- $\quad$ external changes on the surface of the bone.

In anterior rotation, the rotation centres are:

- premolar area,

- $\quad$ incisal edge of lower anterior teeth.

In posterior rotation, the rotation centres are:

- condyle

- posterior molars in occlusion.

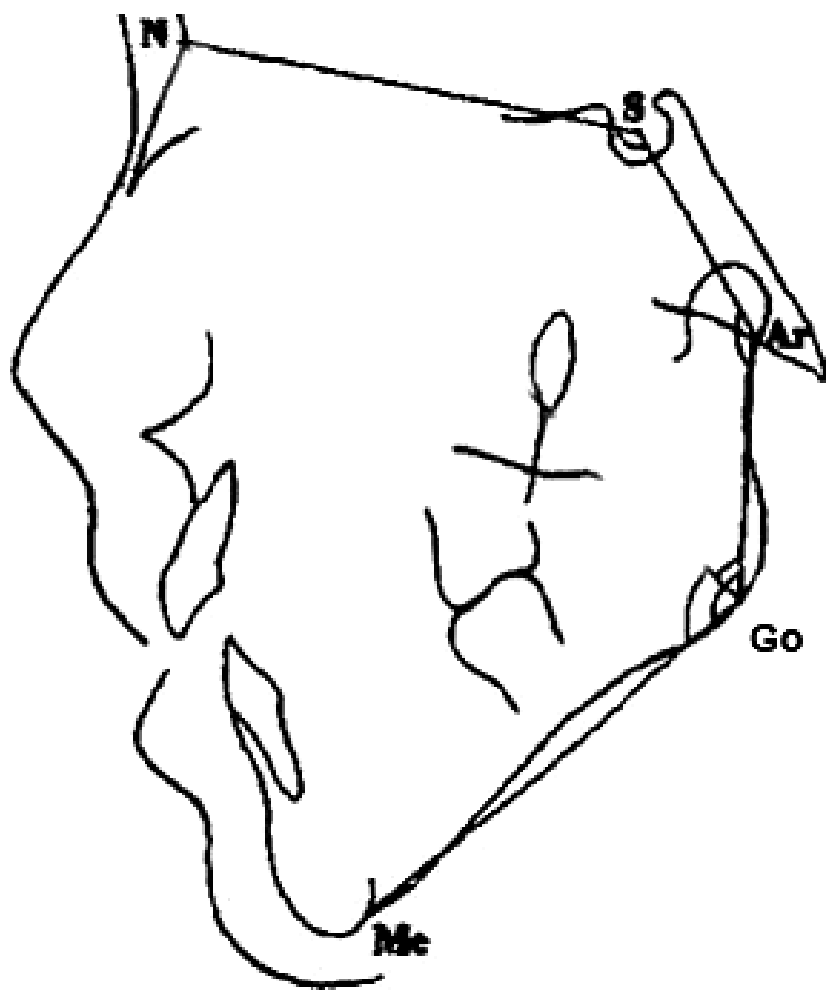

Figure 2. Anterior and posterior face height.

The percent ratio represents the ratio of the posterior SGo to the anterior face height NMe. This percent ratio should be from $62 \%$ to $65 \%$ and then the face grows without rotation. If the percentage is higher, the face grows with anterior and if the percentage is lower it grows with posterior rotation $(3,15)$.

The gonial angle is divided into two angles, the upper ArGoN whose average value is $52-55^{\circ}$, and the lower NGoMe with the average value of $70-75^{\circ}(3,16)$. If the value of the upper angle is higher the face grows with anterior rotation and if its value is lower it grows with posterior rotation.

If the $\mathrm{Y}$ axis angle NSGn is greater than $66^{\circ}$, the face grows with posterior and if the angle is smaller it grows with anterior rotation. The main disadvantage of the 


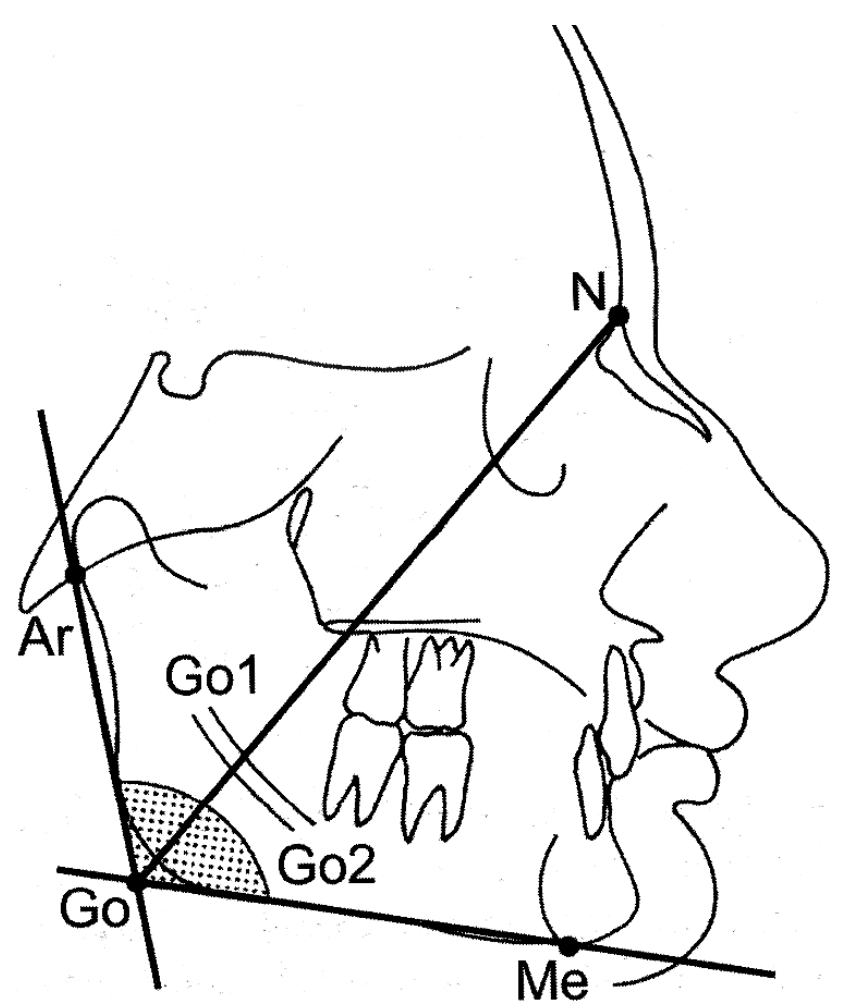

Figure 3. Gonial angle.

metric method is its unreliability because the rotation type can be changed during the course of facial growth.

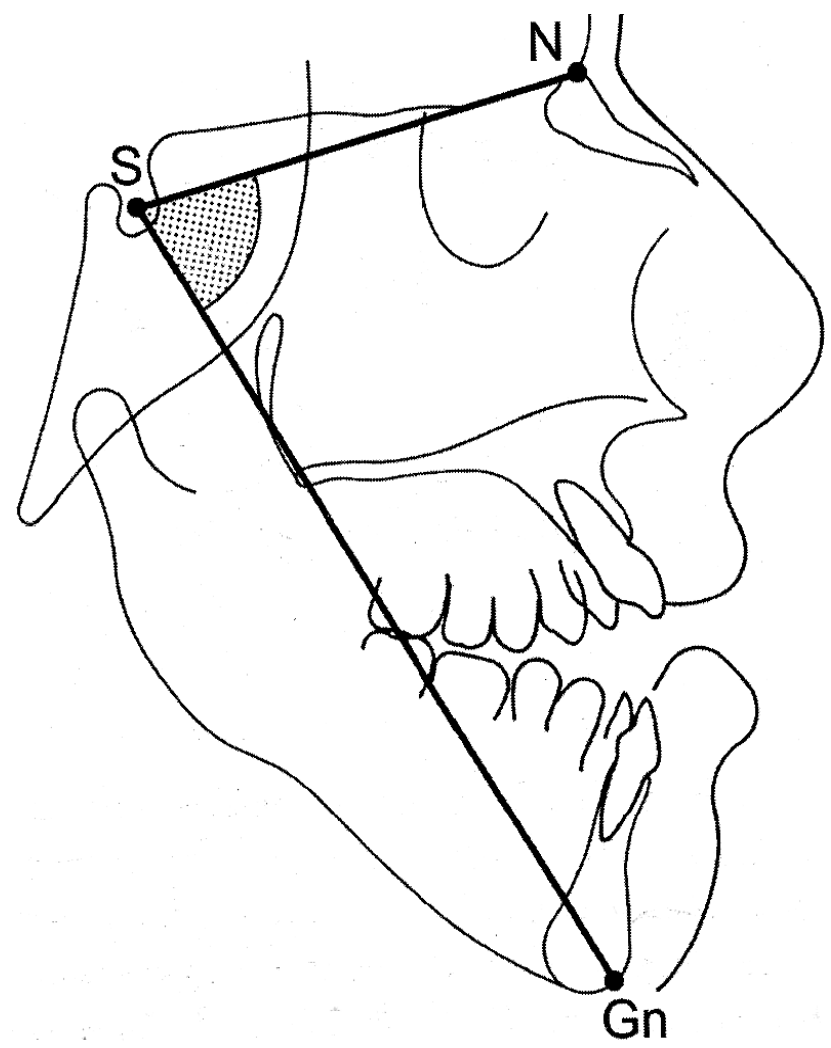

Figure 4. Y axis angle.
The longitudinal method

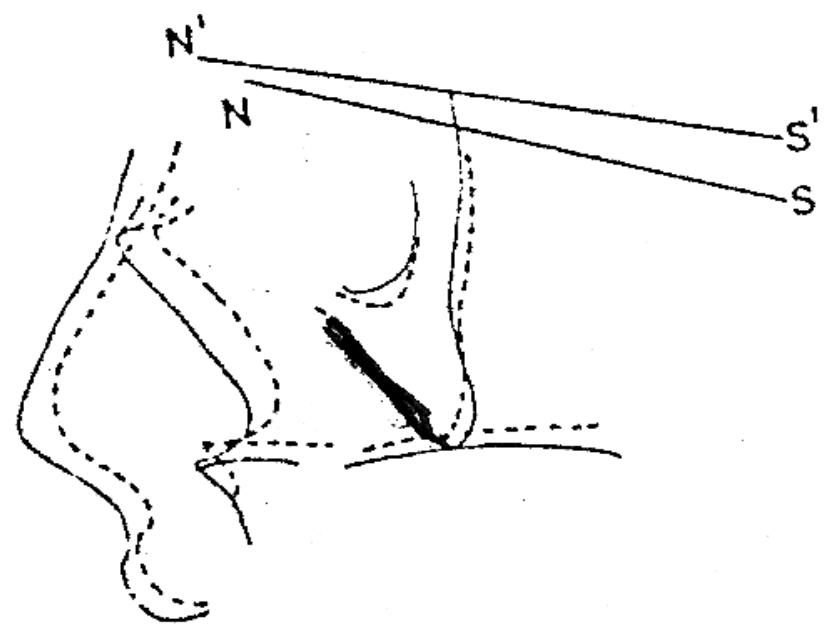

Figure 5. Superposition.

The longitudinal method involves growth monitoring over a period of time and making cephalograms at certain intervals. Superposition of the cephalograms reveals the rotation type. As all longitudinal methods, it is rather inconvenient because it involves a long-term monitoring. Superposition is performed by using mandibular bone structures which are considered stable. Based on the angles that enclose the NS plane in the first and second cephalogram, the type of viscerocranium rotation can be undoubtedly established. If the lines NS and N'S' converge with their front ends, the face has developed with anterior rotation, and if they converge with their back ends the face has rotated backwards. They seldom stay parallel, in which case we establish a balanced growth both in the sagittal and vertical plane $(1,2,17,18)$.

\section{The structural method}

The structural method implies determination of the rotation type based on a cephalogram. Some mandibular morphological characteristics are formed as a result of remodelling that occurs during growth, and they can help in determination of the growth type. According to Bjork, they are the following:

- inclination of the condyle - forward in anterior and backward in posterior rotation,

- $\quad$ the curvature of the mandibular channel is much more prominent in anterior than in posterior rotation when it can be almost straight,

- $\quad$ the contour of the lower edge of the mandible in anterior rotation the pre-angular notch is hardly present,

- inclination of the mandibular symphysis in anterior rotation is forward while in posterior rotation it is backward, and 
- the lower anterior face height is increased in posterior and decreased in anterior rotation $(1,3$, $19,20)$.

In assessment of facial growth, Hasund advocates separate maxillary and mandibular rotations. There can be:

- simultaneous anterior inclination (slight anterior rotation), which is favourable for therapy (on average, in $50 \%$ of the population),

- anteinclination of the maxilla and posterior inclination of the mandible represents a divergent growth of the bases, which is particularly unfavourable in retrognate faces (present in 9.5\% of the population),

- posterior inclination of the maxilla and anteinclination of the mandible lead to a deep bite $(36 \%)$, which represents a convergent growth of the jaw bases

- $\quad$ simultaneous posterior inclination is a risk factor for the therapy of extremely retrognate and prognate faces $(4.5 \%)(3)$.

\section{PLANES AND LINES}

Changes of the entire face are usually studied through the planes in the cranial base, because, compared to other areas of the head, this part reaches its full size early in life (around year 8), therefore it is relatively stable. The most frequently used planes and lines for superposition in the skull base are the following:

1. The Bolton plane Bo-Na. The Bolton point (Bo) is the highest point in the posterior contour of the occipital condyle in the cephalogram. If this part is not clearly visible in the cephalometric radiograph, then the Bolton point is found at the half way distance between the Basion and Opisthion points. From the point $\mathrm{S}$ a vertical line is drawn through this plane, while the registration point $\mathrm{R}$ is the midpoint of this vertical line. Superposition is performed by using the vertical line, with overlapping at the point $R$, while the Bolton planes of the first and the second cephalogram are kept parallel.

2. The Basion -Nasion plane with registration at the point Ba. This plane was recommended by Downs, and the procedure is the same as with the Bolton plane. The two planes, Bo-Na and $\mathrm{Ba}-\mathrm{Na}$, have an advantage to be defined by the two distant points, but a disadvantage to have a spheno-occipital synchondrosis between them, because the spheno-occipital synchondrosis is still active at the age when orthodontic treatment is applied.

3. Sella-Nasion line with registration at the point $S$ represents one of the most frequently used superposition lines, which is due to the fact that points that define it are easily located. However, it should not be forgotten that during growth these two points can change their position independently of each other. However, the point $\mathrm{S}$ is more stable.

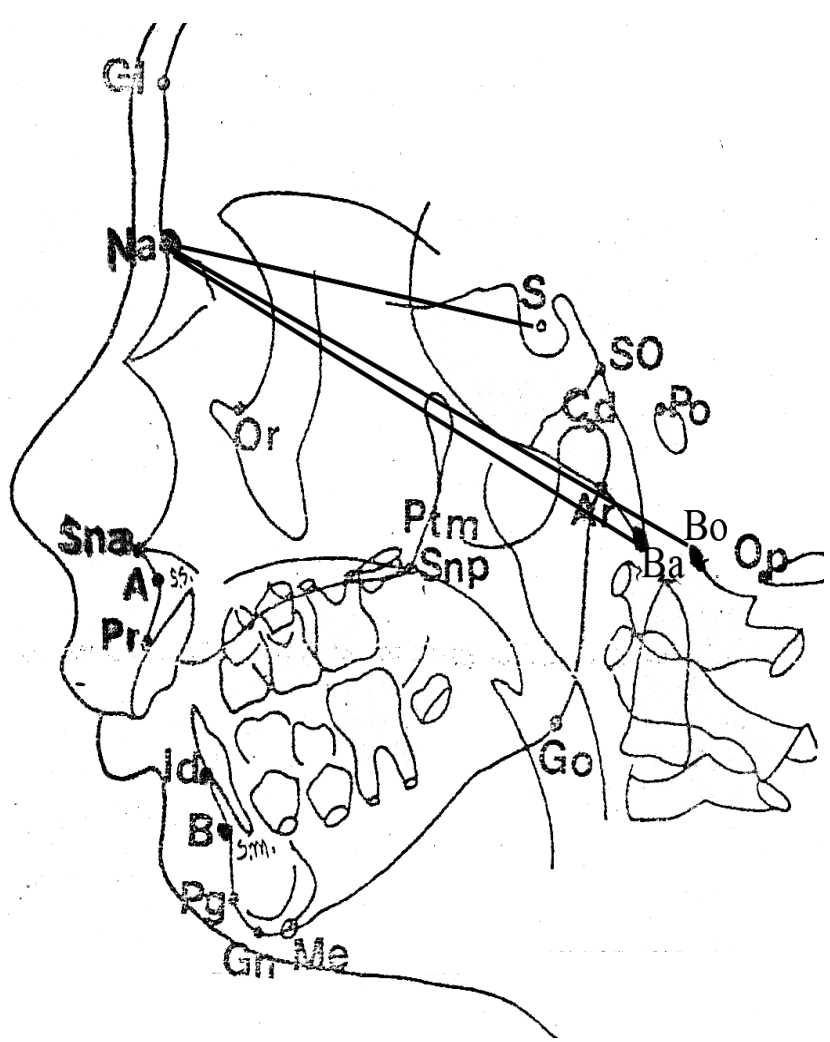

Figure 6. The stuctural method.

Superposition, as recommended by various authors, can be done using bone contours. For example, De Coster's reference line starts from the anterior wall of the sella turcica and follows the contour of the body of sphenoid bone, the ethmoid bone (lamina cribrosa) and the inner surface of the frontal bone. It is very suitable for superposing because its length insures accurate superposition and it does not change after the age of seven, as stated by different authors.

\section{CONCLUSION}

At present, it is quite obvious that the opinion that facial growth process ends at the age of 13 to 19 years or in early 20s should be reconsidered. We should also be aware that growth takes place in all three planes of space. Growth in width is the first to reach adult levels, and it usually stops at the beginning of puberty or continues after that but at a very slow rate. A-P growth continues after puberty, it is slow but visible even during the adult age. The vertical growth (which stops last) persists after puberty and continues at a moderate rate throughout the adult age both in men and women. Researchers are interested to know if and to what extent the growth of posterior molars induces changes in the size of jaws, in their mutual relationships, and thus the changes in the face. 


\section{REFERENCES}

1. Bjork A. Prediction of mandibular growth rotation. Am J Orthod 196; 55: 585-99.

2. Filipović G, Janošević M. Tip rasta lica kod osoba sa skeleton otvorenim zagrižajem. Acta Stom Naissi 2004; 20: 303-17.

3. Jakšić N, Šćepan I, Glišić B. Ortodontska dijagnostika. Beograd: Autorsko izdanje, 2000.

4. Proffit WB. Contemporary orthodontics. St. Louis, London, Toronto: Mosby Co., 1993.

5. Markovic M, ur. Ortodoncija. Beograd, Zagreb: Medicinska knjiga, 1998.

6. Bingmer M, Özkan V, Jo JM, Lee KJ, Baik HS, Schneider G. A new concept for the cephalometric evaluation of craniofacial patterns. Eur J Orthod 2010; 32: $645-54$

7. Jakšic N. Longitudinalno ispitivanje kraniofacijalnog rasta u dece od 5 do 10 godine života. Doktorska disertacija. Beograd: Stomatološki fakultet, 1985.

8. Claes P, Walters M, Vandermeulen D, Clement JG. Spatially-dense 3D facial asymmetry assessment in both typical and disordered growth. J Anat 2011; 219: 444-55.

9. Janoševic M. Karakteristike denticije i kraniofacijalnog tipa osoba sa teskobom. Doktorska disertacija. Niš: Medicinski fakultet, 1995.

10. Richmond S, Toma AM, Zhurov AI. New perspectives on craniofacial growth Orthod Fr 2009; 80: 359-69.

11. Čutović T, Pavlović J, Kozomara R. Rendgenkefalometrijska analiza dimenzija kondilarnog nastavka kod osoba sa mandibularnim prognatizmom. Vojnosanitet Pregl 2008; 65: 513-9.

12. Drahorádová M, Müllerová Z, Smahel Z. Changes of craniofacial growth and development in males with complete unilateral cleft lip and palate between the age of 5 to 20 years. Acta Chir Plast 1997; 39: 82-7.
13. Moffitt AH. Discovery of pathologies by orthodontists on lateral cephalograms. Angle Orthod 2011; 81: 60-5.

14. Popovich F, Thompson GW. Craniofacial templates for orthodontic case analysis. Am J Orthod 1977; 71: 4062.

15. Celli D, Gasperoni E, Oliva B, Deli R. Assessment of mandibular growth and response to functional appliance treatment in prepubertal patients with different auxologic categories. Prog Orthod 2010; 11: 20-6.

16. Seliem EN, Attia KH, Al-Hadithiy S, Mostafa YA. Soft tissue cephalometrics: an overdue evaluation. World J Orthod 2009; 10: 301-4.

17. Stojanović ZM, Milić J, Nikolić P. Rendgen kefalometrijska procena linearnih $\mathrm{i}$ angularnih parametara na bazi lobanje kod dece sa III skeletnom klasom. Vojnosanitet Pregl 2007; 64: 604-10.

18. Shahabi M, Ramazanzadeh BA, Mokhber N. Comparison between the external gonial angle in panoramic radiographs and lateral cephalograms of adult patients with Class I malocclusion. J Oral Sci 2009; 51: 425-9.

19. Sadat-Khonsari R, Dathe H, Knösel M, Hahn W, Kubein-Meesenburg D, Bauss O. Geometric influence of the sagittal and vertical apical base relationship on the ANB angle. J Orofac Orthop 2009; 70: 152-8.

20. Endo T, Ozoe R, Kojima K, Shimooka S. Congenitally missing mandibular incisors and mandibular symphysis morphology. Angle Orthod 2007; 77: 107984.

21. Ongkosuwito EM, Dieleman MM, Kuijpers-Jagtman AM, Mulder PG, van Neck JW. Linear mandibular measurements: comparison between orthopantomograms and lateral cephalograms. Cleft Palate Craniofac J 2009; 46: 147-53. 